\title{
Vascular endothelial growth factor ameliorated palmitate-induced cardiomyocyte injury via JNK pathway
}

\author{
Shi-ya Wang ${ }^{1,2} \cdot$ Cao Zou $^{1} \cdot$ Xiao-feng $\mathrm{Liu}^{2} \cdot$ Yon-jin $\mathrm{Yan}^{2} \cdot$ Shun-zhon $\mathrm{Gu}^{2} \cdot \mathrm{Xun} \mathrm{Li}^{1}$
}

Received: 1 June 2021 / Accepted: 16 August 2021 / Published online: 17 November 2021 / Editor: Tetsuji Okamoto

(c) The Author(s) 2021

\begin{abstract}
Enhanced apoptosis of cardiomyocytes in suffering overloaded saturated fatty acids (SFAs) can result in myocardial infarction and cardiac dysfunction. The function of vascular endothelial growth factor (VEGF) in cardiomyocyte protection was not clearly described. To investigate the preservative effects of VEGF sensitization on ceramide-mediated programmed cell death of cardiomyocytes, palmitate-induced injury in $\mathrm{H} 9 \mathrm{c} 2$ cells was established as an in vitro model. Results revealed that $0.5 \mathrm{mM}$ palmitate application effectively led to debased viability and activated apoptotic factors. A significant time-dependent relation between PAL and cardiomyocyte injury was observed. The apoptosis rate was increased greatly after $16 \mathrm{~h}$ of treatment with $0.5 \mathrm{mM}$ PAL. In addition, cell viability was restored by VEGF overexpression during treatment with $0.5 \mathrm{mM}$ PAL. Reduced apoptosis rate and expression of caspase 3, Bax, and NF- $\mathrm{KB}$ p65 were observed in this process, while boosted Bcl-2, p-JNK/ JNK expression and activity of caspase 3 were checked. However, p-ERK/ERK levels did not exhibit a significant change. These findings indicated the protective effects of VEGF in confronting the ceramide-induced cardiomyocyte apoptosis, and would devote therapeutic targets for cardiovascular safeguard in dealing with fatty acid stress.
\end{abstract}

Keywords Palmitate $\cdot$ VEGF $\cdot$ Cardiomyocyte $\cdot$ Apoptosis $\cdot$ Caspase $3 \cdot \mathrm{NF}-\mathrm{\kappa B}$

\section{Introduction}

Recent studies support the hypothesis that cardiomyocytes harbor no ability of self-renewal and replication, for they are terminally differentiated cells (Heallen et al. 2019). Thus, it is believed that the damage and apoptosis of cardiomyocytes are mainly ascribed to cell necrosis (Nasser et al. 2020). However, the latest research shows that cardiomyocyte apoptosis is also an important biological basis for the normal physiological function of the heart (Heallen et al. 2019). The rapid changes in the human diet, and the concomitant increase in human fat deposition, have led to a high incidence of obesity, diabetes, and cardiovascular diseases ( $\mathrm{Li}$ et al. 2020). Increases in serum lipid levels result in damage to and irritation of the cardiovascular system; particularly, ectopic fat deposition places an additional burden on the

Xun Li

xunli58@126.com

1 Department of Cardiology, The First Affiliated Hospital of Soochow University, 188 Shizi Street, Suzhou, , Jiangsu, China

2 Hai' an People's Hospital, Nantong, China heart, which can lead to myocardial injury (Lin et al.2020). Energy supply to the adult heart mainly relies on fatty acids; abnormal fatty acid metabolism is often accompanied with heart disease or systemic disease (Cacicedo et al. 2005; Zhou et al. 2020). It has been reported that acute myocardial ischemia, diabetes, and obesity patients have an increased risk of abnormal deposition of myocardial fat, leading to heart failure (Puzyrenko et al. 1999).

Palmitate (PAL), a saturated fatty acid, has been shown to accumulate in cardiomyocytes, vascular smooth muscle cells, hepatic cells, and islet beta cells (Chai and Liu 2007; Quan et al. 2014; Gorgani-Firuzjaee et al. 2014; Le et al. 2020; Geng et al. 2020). PAL accumulation in cardiomyocytes can lead to "lipotoxicity" and thus result in cardiomyocyte injury, apoptosis, and heart dysfunction and failure (Kenny and Abel 2019; Tong et al. 2019; Li et al. 2020; Xiong et al. 2020). Transgenic mouse models with abnormal lipid accumulation in the heart demonstrated that an imbalance of lipid uptake and utilization in cardiomyocytes led to apoptosis and contributed to cardiomyopathy (Cheng et al. 2004; Chiu et al. 2005). PAL was also found to induce apoptosis in a variety of cells in vitro; however, the exact molecular and cellular mechanisms by which fatty acids cause apoptosis remain unclear. 

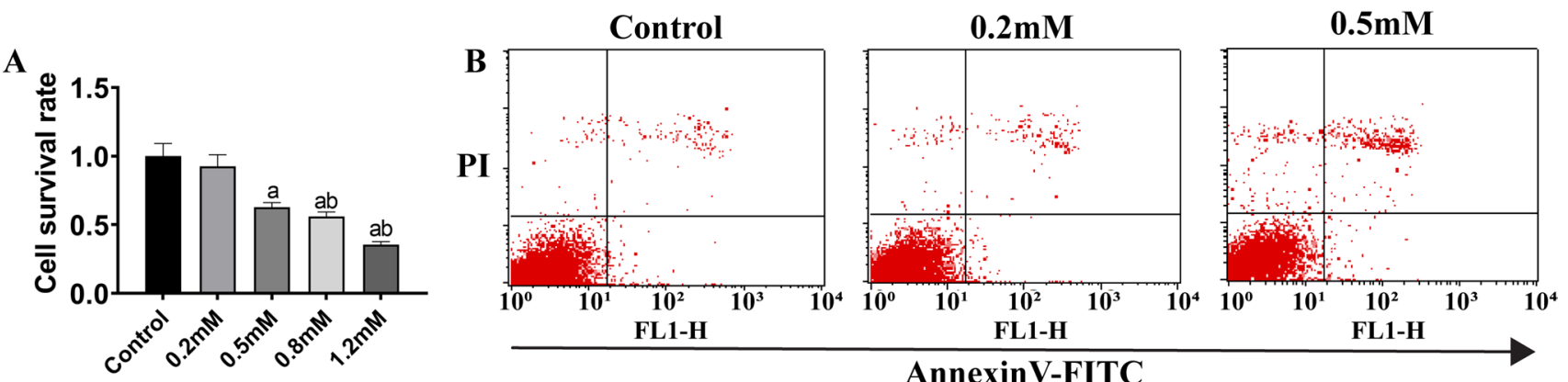

AnnexinV-FITC
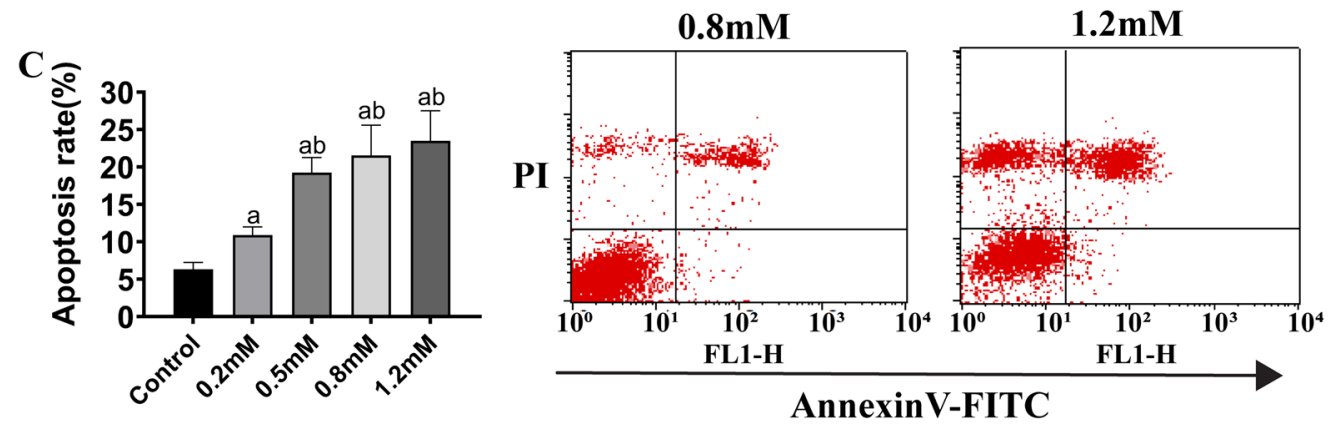

Figure 1 Cell survival and apoptosis after treatment with different PAL concentrations. (A) Cell survival rate. $(\boldsymbol{B})$ Flow cytometry analysis of PAL-treated $\mathrm{H} 9 \mathrm{c} 2$ cells. $(\boldsymbol{C})$ Statistical analysis of the flow

Vascular endothelial growth factor (VEGF), also known as vascular osmotic factor, is a member of the vascular endothelial growth factor family and exerts multiple physiological effects, including proangiogenesis effects, blood vessel dilation, increasing vascular permeability, and promoting cell proliferation, differentiation, and viability. Extensive studies show its role in the fields of diabetes, rheumatoid arthritis, kidney disease, cardiovascular disease, tumor, and central nervous system diseases (Ferrara 2004; Ho and Kuo 2007; Li et al. 2016). VEGF induced migration and proliferation of vascular endothelial cells in the process of angiogenesis and promoted the secretion of protease and fibrinogen activator, which stimulated the cells to escape from the matrix by degrading the vascular basement membrane (Oka et al. 2014). Platelet-derived growth factors (PDGFs) are secreted by endothelial cells under the stimulation of VEGF, thus maintaining vascular homeostasis (Bowers et al. 2020). VEGF-A, one of the five members in the VEGF family, shows the highest specificity and the strongest physiological effects (Harper and Bates 2008; Rennel et al. 2008). VEGF directly interacts with mitogens in endothelial cells and thus promotes the permeability of blood vessels, increases blood oxygen supply, and enhances the proliferation of vascular endothelial cells (Huang et al. 2020; Song and Finley 2020). Inhibition of extracellular signal-regulated kinase (ERK)-MAPK signaling by PD98059 significantly increased cardiomyocyte apoptosis, caspase 3 activity, and the myocardial defect area, and the effects on cytometry results. (a) $P<0.05$ compared with the control group; (b) $P<0.05$ compared with the $0.2 \mathrm{mM}$ group. $n=7$ for cell survival investigation and $n=3$ for FACs analysis

apoptosis could be reversed by the administration of fasudil (a Rho kinase inhibitor) (Czabotar et al. 2014). The ERK-MAPK pathway promotes the remodeling of myocardial cell morphology in glucocorticoid-induced cardiomyocyte injury (Yang et al. 2015).

In this study, we observed the effects of VEGF overexpression on myocardial apoptosis in a PAL-induced cardiomyocyte apoptosis model and detected the changes of the MAPK pathway, in order to explore the mechanisms and protective factors of myocardial apoptosis injury in the cellular and molecular levels.

\section{Results}

Effects of different PAL concentrations on cell survival and apoptosis To determine the suitable concentration of palmitate (PAL) in inducing cardiomyocyte cell injury model, $\mathrm{H} 9 \mathrm{c} 2$ cells were treated with PAL at final concentrations of $0.2,0.5,0.8$, and $1.2 \mathrm{mM}$ and collected after $24 \mathrm{~h}$ to measure cell viability. Significant decrease was observed in the $0.5 \mathrm{mM}$ group $(P<0.05), 0.8 \mathrm{mM}$ group $(P<0.01)$, and $1.2 \mathrm{mM}$ group $(P<0.001)$ when compared with the control group, while significant difference was only detected in the $0.8 \mathrm{mM}$ group $(P<0.05)$ and $1.2 \mathrm{mM}$ group $(P<0.01)$ compared with the $0.2 \mathrm{mM}$ group (Figure $1 A)$. To explore the effects of PAL on $\mathrm{H} 9 \mathrm{c} 2$ cell apoptosis, the PAL incubated cells above were collected and analyzed by 

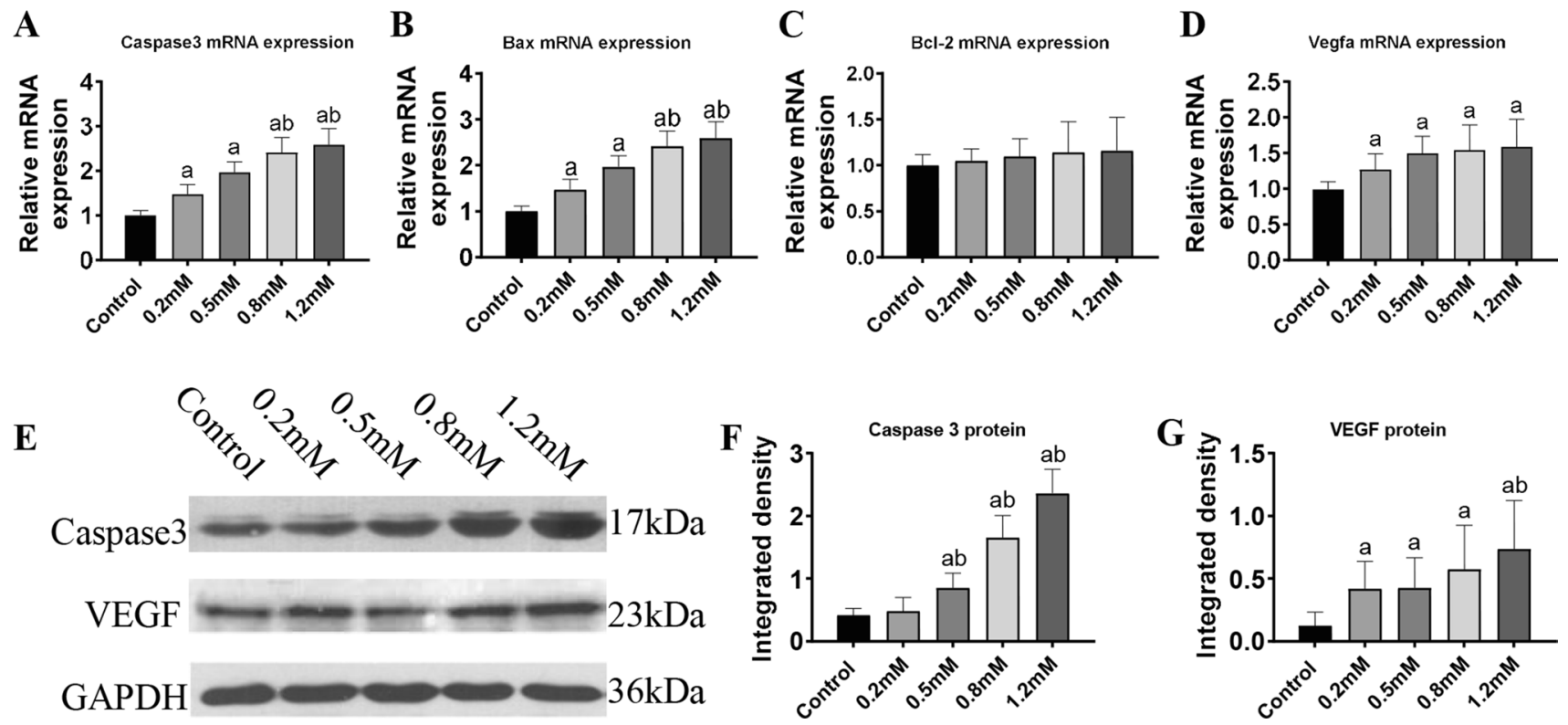

Figure 2 Expression of apoptosis-related genes after treatment with different concentrations of PAL. (A) Casp3 mRNA expression. (B) Bax mRNA expression. (C) Bcl-2 mRNA expression. (D) Vegfa mRNA expression. $(\boldsymbol{E})$ Western blot analysis of caspase 3 and VEGF.

flow cytometry (FACs). The apoptosis rates in the $0.2 \mathrm{mM}$ $(P<0.05), 0.5 \mathrm{mM}(P<0.01), 0.8 \mathrm{mM}(P<0.01)$, and $1.2 \mathrm{mM}(P<0.01)$ groups were significantly higher than that in the control group. In addition, the apoptosis rates were significantly enhanced in the $0.5 \mathrm{mM}(P<0.05), 0.8 \mathrm{mM}$ $(P<0.01)$, and $1.2 \mathrm{mM}$ groups $(P<0.01)$ compared to the $0.2 \mathrm{mM}$ group (Figure $1 B, C$ ). These data indicated that PAL successfully influenced myocardial cell viability and apoptosis in a certain range of concentrations.

PAL altered expression of apoptosis-related genes To investigate the variations of apoptosis-related genes after PAL incubation, H9c2 cells were incubated with PAL at final concentrations of $0.2,0.5,0.8$, and $1.2 \mathrm{mM}$ for $24 \mathrm{~h}$. Transcriptional alteration of Casp 3 expression enhanced continuously after PAL incubation in the $0.2 \mathrm{mM}(P<0.05), 0.5 \mathrm{mM}$ $(P<0.01), 0.8 \mathrm{mM}(P<0.01)$, and $1.2 \mathrm{mM}(P<0.01)$ groups when compared with the control group, while its expression was significantly higher in the 0.8 and $1.2 \mathrm{mM}$ groups compared with that in the $0.2 \mathrm{mM}$ group $(P<0.05)$ (Figure $2 A$ ). In addition, expression of Bax was enhanced significantly in the $0.2 \mathrm{mM}$ group $(P<0.05)$ and the 0.5 , 0.8 , and $1.2 \mathrm{mM}$ groups $(P<0.01)$ compared to that in the control group, while its expression was higher in the 0.8 and $1.2 \mathrm{mM}$ groups compared to that in the $0.2 \mathrm{mM}$ group $(P<0.05)$ (Figure $2 B)$. Concurrently, Vegfa expression was significantly higher in the $0.2,0.5,0.8$, and $1.2 \mathrm{mM}$ groups than that in the control group $(P<0.05)$ (Figure $2 D)$. However, $B c l-2$ expression was not significantly different in the

(F) Relative gray density analysis for caspase 3. (G) Relative gray density analysis for VEGF. (a) $P<0.05$ compared with the control group; (b) $P<0.05$ compared with the $0.2 \mathrm{mM}$ group. $n=8$ for mRNA detection and $n=3$ for blots

$0.5,0.8$, and $1.2 \mathrm{mM}$ groups compared with the $0.2 \mathrm{mM}$ group $(P>0.05)$ (Figure 2C).

To determine the changes of the protein expression of caspase 3 and VEGF, PAL incubated H9c2 cells were collected and had undergone western blot analysis. Results revealed that enhanced caspase 3 expression was checked in the $0.5,0.8$, and $1.2 \mathrm{mM}$ groups compared to the control group $(P<0.05, P<0.01$, and $P<0.001$, respectively). Furthermore, caspase 3 levels were significantly higher in the $0.5,0.8$, and $1.2 \mathrm{mM}$ groups compared to that in the $0.2 \mathrm{mM}$ group $(P<0.05, P<0.01$, and $P<0.001$, respectively) (Figure $2 E, F)$. Similarly, a remarkable increase in VEGF expression was observed in the 0.8 and $1.2 \mathrm{mM}$ groups compared with the control group $(P<0.05)$, while no significant difference was detected compared with the $0.2 \mathrm{mM}$ group $(P>0.05)$. In conclusion, the expression of apoptosis-related genes was enhanced in a dose-dependent way after PAL stimulation for $24 \mathrm{~h}$.

Effects of different incubation times with palmitate on cell survival and gene expression Considering the optimal effects on gene expression and cell viability, based on the above results, a PAL concentration of $0.5 \mathrm{mM}$ was chosen for subsequent experiments. To analyze the effects of different incubation times on cell injury and apoptosis, cells were divided into the $0,4,8,16,24$, and 48 h groups, and cell viability at each time point was examined by MTT assay. Results showed that a significant decrease was observed at $8 \mathrm{~h}(P<0.05), 16 \mathrm{~h}(P<0.01), 24 \mathrm{~h}(P<0.01)$, and $48 \mathrm{~h}$ 

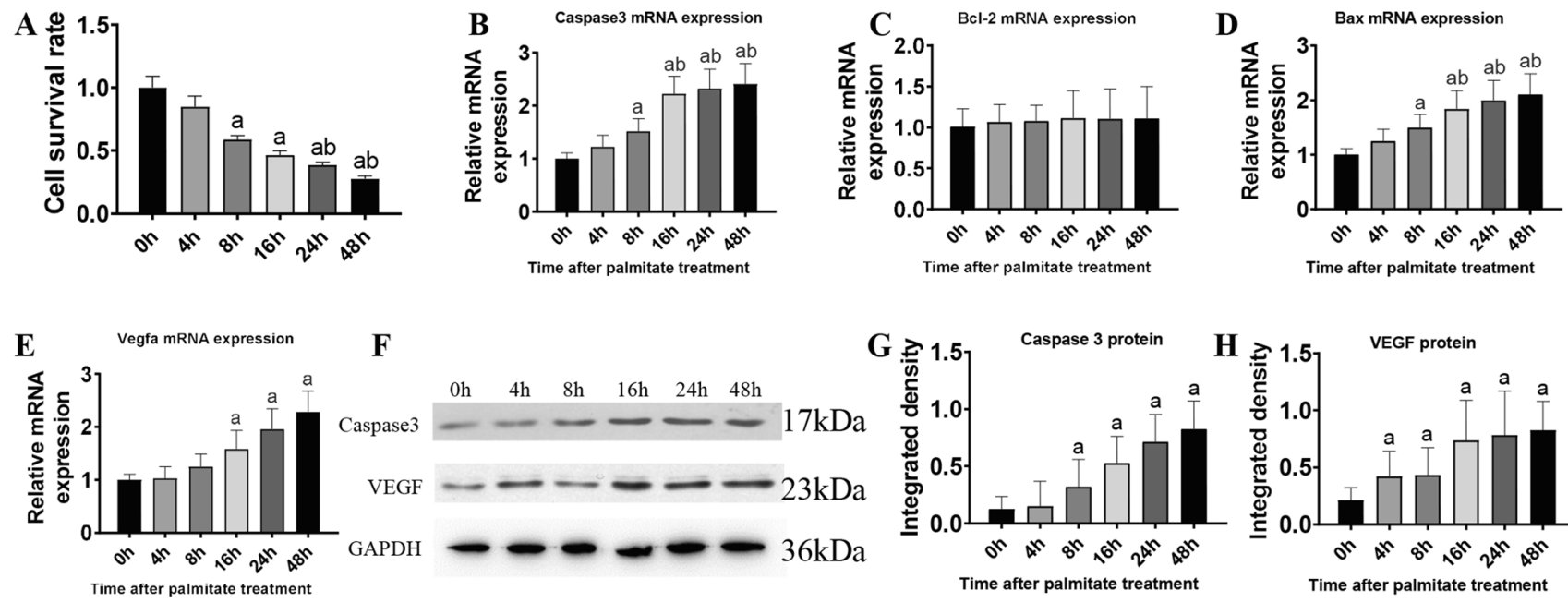

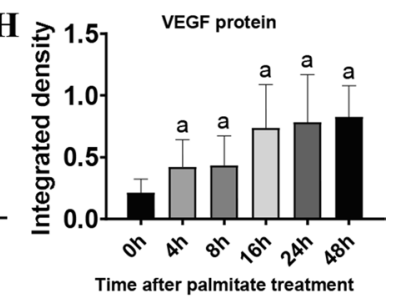

Figure 3 Incubation time of cardiomyocytes with PAL influenced cell survival and the expression of apoptotic genes. (A) Cell survival rate. (B) Casp3 mRNA expression. (C) Bcl-2 mRNA expression. (D) Bax mRNA expression. (E) Vegfa mRNA expression. $(\boldsymbol{F})$ Western blot analysis of the expression of caspase 3 and VEGF. $(\boldsymbol{G})$

$(P<0.01)$ compared to the $0 \mathrm{~h}$ group, and it was significantly decreased at $24 \mathrm{~h}$ and $48 \mathrm{~h}$ compared to the $8 \mathrm{~h}$ group $(P<0.05)$ (Figure 3A).

To detect the variations of apoptotic-related genes after incubation of PAL at different time points, mRNA and protein of H9c2 cells were analyzed. The transcriptional expression of Casp3 was significantly higher at $8 \mathrm{~h}(P<0.05)$ and $16 \mathrm{~h}, 24 \mathrm{~h}$, and $48 \mathrm{~h}(P<0.01)$ compared to $0 \mathrm{~h}$ (Figure $3 B$ ). The expression of $\mathrm{BCl}-2$, an antiapoptotic gene, showed a slight increase at different time points, but no statistical difference was observed $(P>0.05)$ (Figure $3 C$ ). The expression of $B a x$, a proapoptotic gene, was significantly higher at $8 \mathrm{~h}(P<0.05)$, and $16 \mathrm{~h}, 24 \mathrm{~h}$, and $48 \mathrm{~h}(P<0.01)$ compared to the control group (Figure 3D). Vegfa expression at $16 \mathrm{~h}$ $(P<0.05)$, and $24 \mathrm{~h}$ and $48 \mathrm{~h}(P<0.01)$ was significantly increased compared to the $0 \mathrm{~h}$ group (Figure $3 E$ ).

Western blot analysis was taken to investigate the expression of caspase 3 and VEGF in PAL incubated H9c2 cells. Expression of caspase 3 was significantly enhanced in $8 \mathrm{~h}$, $16 \mathrm{~h}, 24 \mathrm{~h}$, and $48 \mathrm{~h}$ than that in the control group $(P<0.05$, $P<0.01, P<0.01$, and $P<0.001$, respectively), while its expression was significantly higher in the 16,24 , and $48 \mathrm{~h}$ groups compared to that in the $4 \mathrm{~h}$ group $(P<0.01)$ (Figure $3 F, G)$. VEGF protein expression also showed a time-dependent increasing trend. A significant increase was observed in the $4 \mathrm{~h}$ and $8 \mathrm{~h}$ groups compared to the $0 \mathrm{~h}$ group $(P<0.05)$. At $16 \mathrm{~h}$, VEGF expression was significantly higher than that in the $4 \mathrm{~h}$ and $8 \mathrm{~h}$ groups $(P<0.01)$ (Figure $3 F, H$ ).
Relative gray density analysis for caspase 3. (H) Relative gray density analysis for VEGF. (a) $P<0.05$ compared with the control group; (b) $P<0.05$ compared with the 4 h group. $n=8$ for mRNA detection and $n=3$ for blots

In summary, the apoptosis rate exhibited a time-dependent increase after PAL stimulation and the expression of apoptosis-related genes and VEGF was enhanced.

VEGF overexpression ameliorated cell injury To explore the role of VEGF in the regulation of the apoptosis process, a plasmid containing human VEGFA cDNA was constructed and administered to $\mathrm{H} 9 \mathrm{c} 2$ cells. Results showed that the expression of VEGF-A was boosted at the transcriptional level (48 h; Figure $4 A$ ) and the translational level (24 h, $48 \mathrm{~h}$; Figure $4 B, C$ ). Moreover, no significant difference in cell apoptosis rate was found by flow cytometry $(P>0.05)$ (Figure 4D, E).

We then measured the expression levels of apoptosisrelated factors at 0,24 , and $48 \mathrm{~h}$. The expression level of CASP3, a key executor of the apoptotic pathway, was significantly decreased in the $24 \mathrm{~h}$ group $(P<0.05)$, and its expression level decreased significantly after $48 \mathrm{~h}$ of incubation with PAL $(P<0.01)$ (Figure $5 A)$.

A similar decreasing trend was observed for caspase 3 protein expression at $24 \mathrm{~h}(P<0.05)$ and $48 \mathrm{~h}(P<0.05)$ (Figure $5 E, F$ ). Compared with the control group, the expression level of the antiapoptotic factor $\mathrm{Bcl}-2$ exhibited no significant difference in the $24 \mathrm{~h}$ group $(P>0.05)$, while it was significantly increased at $48 \mathrm{~h}(P<0.05)$ (Figure $5 B)$. On the contrary, Bcl-2 protein expression was significantly higher than that of the control group at $24 \mathrm{~h}(P<0.05)$ and $48 \mathrm{~h}(P<0.01)$ (Figure 5E, $G)$.

Compared with the control group, expression of the proapoptotic factor Bax significantly decreased in the $24 \mathrm{~h}$ group $(P<0.05)$ and the $48 \mathrm{~h}$ group $(P<0.01)$ (Figure $5 C$ ). 

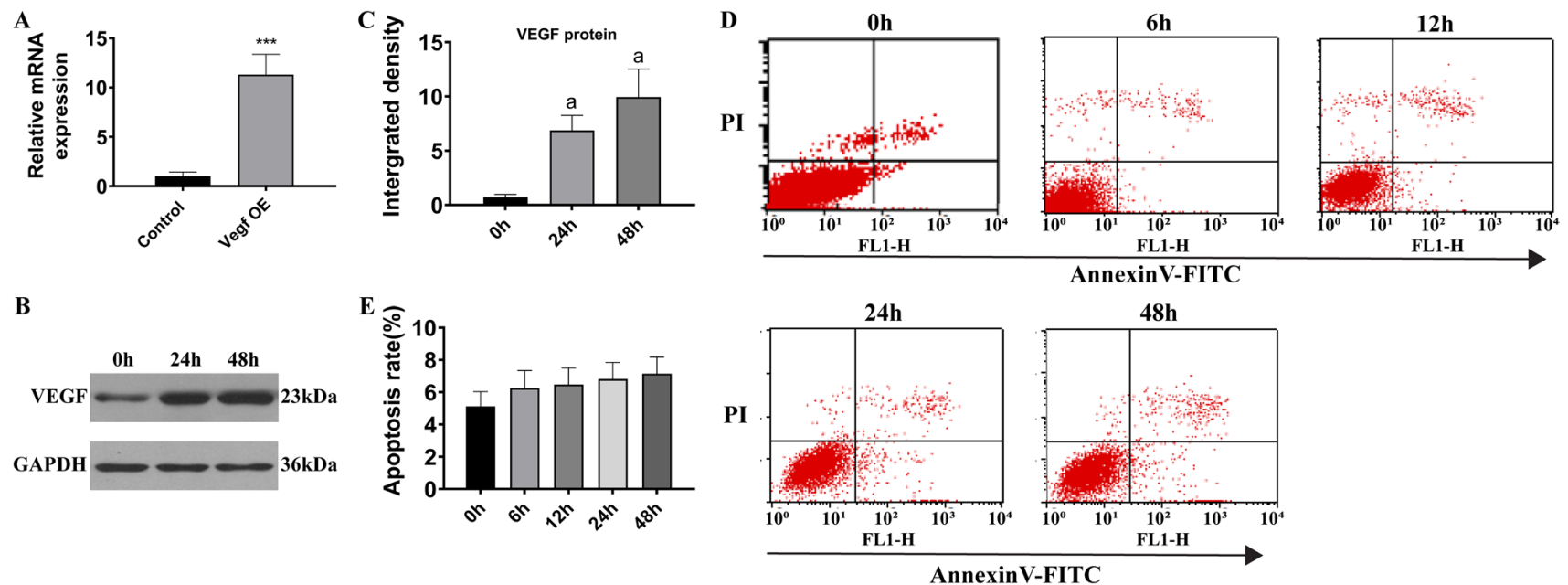

Figure 4 VEGF overexpression reduced the apoptotic effects of PAL. (A) VEGF mRNA expression after exotic transfection. (B) Western blot analysis of VEGF. (C) Relative gray density analysis for VEGF.

(D) Flow cytometry analysis of the apoptosis of cardiomyocytes. $(\boldsymbol{E})$ Statistical analysis of FACS results. (a) $P<0.05$ compared with the control group. $n=3$
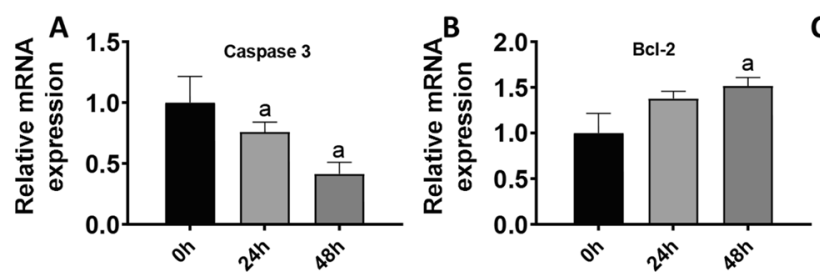

E

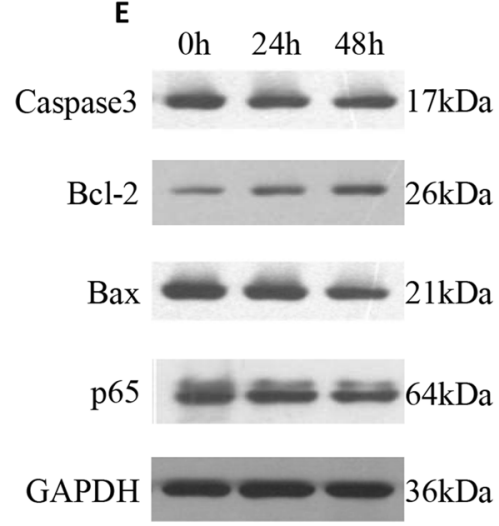

Figure 5 VEGF overexpression reversed the apoptosis of cardiomyocytes. $(\boldsymbol{A}-\boldsymbol{D})$ Transcriptional changes of Casp3, Bcl-2, Bax, and p65 after VEGF overexpression in PAL incubated cardiomyocytes. $(\boldsymbol{E})$ Protein expression of caspase 3, Bcl-2, Bax, and p65. $(\boldsymbol{F}-\boldsymbol{I})$ Relative

Bax protein expression declined at $24 \mathrm{~h}(P<0.05)$ and $48 \mathrm{~h}$ $(P<0.01)$ (Figure $5 E, H)$. Expression of $p 65$, encoding a subunit of the NF- $\mathrm{KB}$ transcriptional complex, was significantly decreased at $24 \mathrm{~h}(P<0.05)$ and $48 \mathrm{~h}(P<0.01)$ compared with the control group (Figure $5 D$ ). Meanwhile, p65 protein expression was significantly lower at $24 \mathrm{~h}(P<0.05)$ and $48 \mathrm{~h}(P<0.01)$ (Figure $5 E, I)$.
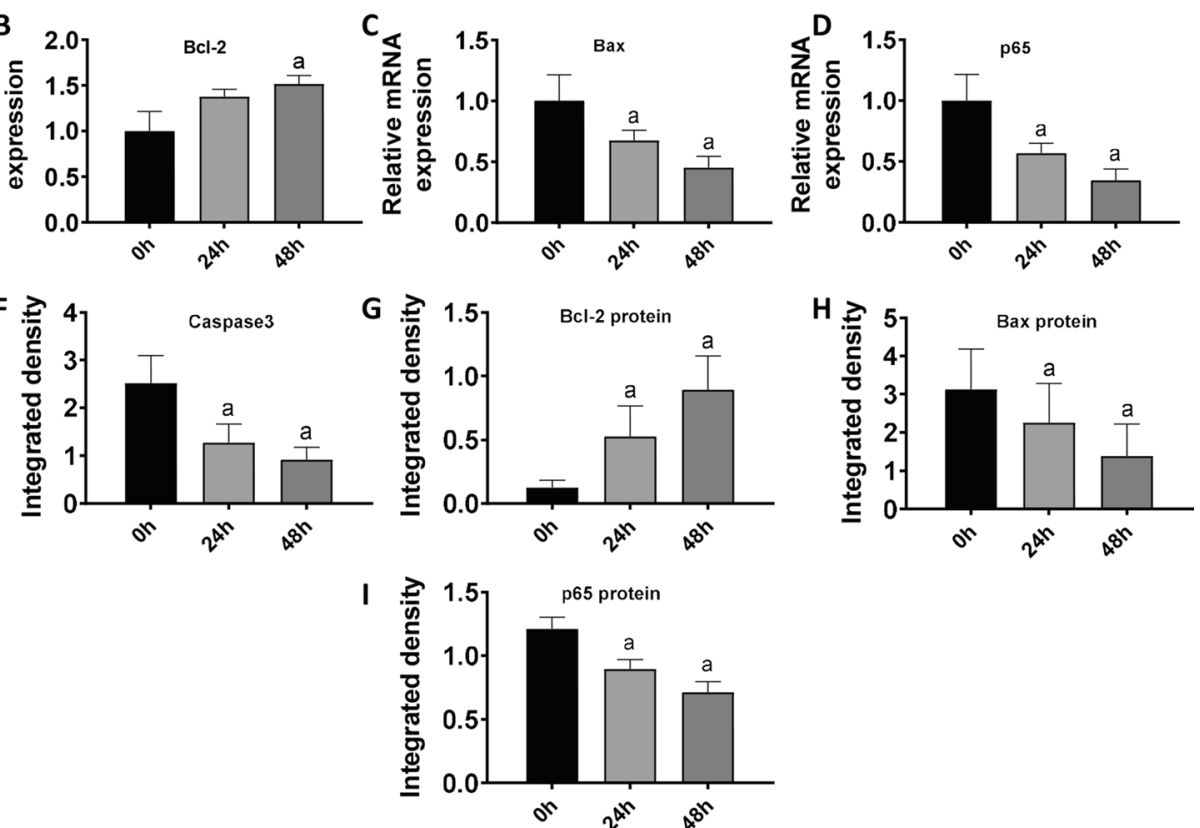

gray density analysis for caspase $3, \mathrm{Bcl}-2$, Bax, and p65 in $(\boldsymbol{E})$. (a) $P<0.05$ compared with the control group. $n=8$ for mRNA detection and $n=3$ for blots

In summary, VEGF-A overexpression increased the cell survival rate and reduced the apoptosis rate after PAL incubation, and VEGF-A overexpression significantly lowered the expression of apoptosis-related factors.

The JNK pathway, but not the ERK pathway, functioned in VEGF-regulated cell apoptosis Studies have shown that the c-Jun N-terminal protein kinase (JNK) and ERK pathways 

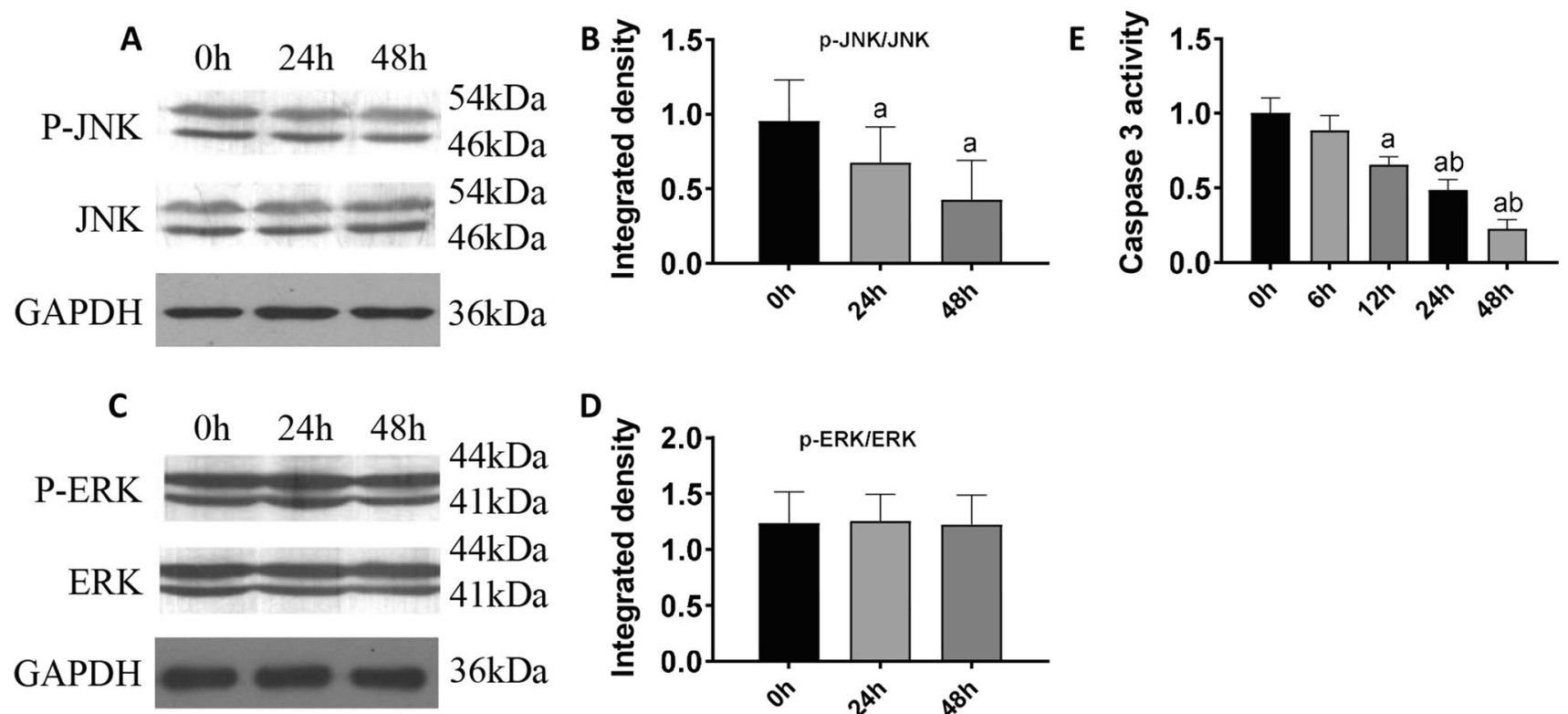

Figure 6 Variation of the JNK and ERK pathways under condition of VEGF overexpression. (A) Protein levels of p-JNK and JNK. (B) Relative gray density analysis for p-JNK and JNK. $(\boldsymbol{C})$ Protein levels of p-ERK and ERK. (D) Relative gray density analysis for p-ERK and

play important regulatory roles in the process of apoptosis. Therefore, we detected their protein expression. The expression level of phosphorylated JNK (p-JNK) was significantly lower in the $24 \mathrm{~h}$ and $48 \mathrm{~h}$ groups than in the control group $(P<0.05)$ (Figure $6 A, B)$; no significant difference was observed in the JNK protein level at 24 and $48 \mathrm{~h}(P>0.05)$ (Figure 6A, B). However, the expression level of phosphorylated ERK (p-ERK) was not significantly different in the 24 and $48 \mathrm{~h}$ groups $(P>0.05)$ (Figure $6 C, D)$, and there was no significant difference in total ERK protein expression between the $24 \mathrm{~h}$ and $48 \mathrm{~h}$ groups $(P>0.05)$ (Figure $6 C, D)$.

After H9c2 cells were transfected with VEGF-A plasmid and control cells were transfected with empty vector, cells were incubated with $0.5 \mathrm{mM}$ PAL for different periods of time and caspase 3 activity was evaluated with the caspase 3 activity assay kit. The results showed that caspase 3 activity in the $12 \mathrm{~h}$ group was significantly lower than that in the control group $(P<0.05)$, and caspase 3 activity in the 24 and $48 \mathrm{~h}$ groups was significantly lower than that in the control group $(P<0.01)$ (Figure $6 E$ ).

Totally, JNK activation, instead of ERK, was involved in the function of VEGF in antagonizing the proapoptotic effects of PAL and ectopic expression of VEGF countered the activity of caspase 3 .
ERK. (E) Enzyme activity of caspase 3. (a) $P<0.05$ compared with the control group; (b) $P<0.05$ compared with the $0.2 \mathrm{mM}$ group. $n=3$ for blots and $n=55$ for enzyme activity analysis

\section{Discussion}

Cardiovascular disease has become the number one challenge endangering human health in today's society according to the World Health Organization (Rodriguez et al. 2014). The age-adjusted prevalence of total heart diseases is 10.6\% based on the 2017 National Health Interview Survey, and the prevalence is $11.0 \%, 9.7 \%, 7.4 \%$, and $6.1 \%$ among whites, blacks, Hispanics, and Asians, respectively (Virani et al. 2020). Statistics from the USA show that in 2018, about 163.6 people per 100,000 standard population died of heart disease, making heart disease the leading cause of death (Xu et al. 2018a, 2020). In the present study, an in vitro model of lipotoxicity-induced cell injury was successfully constructed. After incubation with $0.5 \mathrm{mM}$ PAL for $24 \mathrm{~h}$, cell viability was significantly reduced, apoptosis was upregulated, and VEGF expression was increased. After transient transfection with VEGF, VEGF overexpression ameliorated lipotoxicity-induced cell injury and lowered the activity of JNK.

Ectopically deposited fatty acids in the heart result in lipotoxicity, injury to cardiomyocytes, and myocardial apoptosis (Li et al. 2020). PAL, also known as hexadecane, is a commonly consumed saturated fatty acid. Numerous studies have reported that PAL induced apoptosis in a variety of cells, including Chinese hamster ovary (CHO) cells, rat islet cells, retinal microvascular endothelial cells, and myocardial cells (Sparagna et al. 2000; Listenberger et al. 2001; Yamagishi et al. 2002; Lytrivi et al. 2020). A review 
of the published literature shows that mitochondrial pathways, death receptor pathways, and endoplasmic reticulum pathways are involved in the PAL-induced apoptotic process (Westermann 2010; Vakifahmetoglu-Norberg et al. 2017). Overstimulation by PAL causes irreversible alteration of mitochondrial permeability and osmotic pressure, thus inducing caspase 9 to activate caspase 3 and caspase 7 to cleave downstream substrates (Pradelli et al. 2010). In addition, Bcl-2 family members play an important role in regulating mitochondrial membrane permeability. Bcl-xl and $\mathrm{Bcl}-2$ are distributed in the mitochondrial membrane and the cytoplasm, whereas Bax and Bid are located in the cytoplasm (Czabotar et al. 2014). Mitochondrial damage leads to loss of normal morphology and energy metabolism (Richter et al. 1996). Many questions on the relationship between VEGF and PAL in cardiomyocyte apoptosis still remain to be answered. In the present study, the effects of different concentrations and incubation times of PAL on apoptosis in $\mathrm{H} 9 \mathrm{c} 2$ cells were determined by cell viability assays and analysis of the expression of apoptotic factors. Cells were cultured with medium containing $0.2,0.5,0.8$, and $1.2 \mathrm{mM}$ PAL for $24 \mathrm{~h}$ to determine the optimal PAL concentration to induce the cell injury model. Furthermore, different incubation times $(0,4,8,16,24$, and $48 \mathrm{~h})$ were adopted to screen the appropriate time for the cell injury model construction. In addition, we also detected the levels of the antiapoptotic Bcl-2 and the proapoptotic Bax, as well as the downstream protein caspase 3 . Results showed that PAL increased Bax and caspase 3 levels, while it decreased the expression of VEGF, thus promoting cell apoptosis.

VEGF was reported as a vital factor in the promotion of angiogenesis by inhibiting endothelial cell apoptosis upon PAL treatment (Yang et al. 2015; Xu et al. 2018b). In the present study, we focused on cell survival and apoptosis during PAL incubation to investigate the role of VEGF in cardiomyocytes. Since incubation with PAL boosted the expression of VEGF, we hypothesized that VEGF might play a pivotal role in lipotoxicity-induced myocardial apoptosis. 12-Deoxyphorbol 13-palmitate was reported to inhibit the expression of VEGF in MCF-7 cells, which was inconsistent with the results in the present study, possibly because different cells were used in different studies. Next, VEGF was overexpressed and the effects of VEGF on normal and PAL-treated H9c2 cells were evaluated. The PAL-induced decrease in cell viability was ameliorated by VEGF overexpression by inhibiting Bax and caspase 3 expression, while enhancing Bcl-2 expression.

The JNK/ERK signaling pathway has been reported to be involved in apoptosis. Previous reports indicated that a high fat diet induced activation of JNK, which was reversed by TLR4 knockout (Hu and Zhang 2017). Cellular accumulation of ceramide activated JNK signaling and apoptosis, which was prevented by ceramide synthase 5 (CERS5) knockdown
(Leonardini et al. 2017). JNK activation was observed in PAL-treated cardiomyocytes and attenuated by protein kinase R (PKR) inhibition (Mangali et al. 2019). In the present study, we analyzed the expression of proteins involved in the JNK and ERK pathways in cells overexpressing VEGF after PAL treatment. JNK activity was enhanced after PAL incubation, which was alleviated after VEGF overexpression. However, no significant variation in ERK levels was detected. The results suggest a novel role of VEGF in antagonizing cytotoxicity in cardiomyocytes, indicating a potential therapeutic strategy for cardiac protection.

\section{Materials and methods}

Cell culture and treatments The rat embryonic heart-originated $\mathrm{H} 9 \mathrm{c} 2$ cell line was purchased from the Institution of Biochemistry and Cell Biology, Chinese Academy of Sciences (Shanghai, China), and maintained with high glucose DMEM supplied with 10\% FBS (Gibco, Rockville, MD) in $5 \% \mathrm{CO}_{2}$ containing air at a $37^{\circ} \mathrm{C}$ incubator (Thermo Fisher Scientific, Waltham, MA). Cells were dislocated from the dishes by trypsin and suspended into single cell solution for subsequent tests at $80 \%$ confluency.

Cells were seeded in a 24-well plate and treated with different concentrations of palmitate (PAL, Sigma-Aldrich, St. Louis, MO) at final concentrations of 0.2, 0.5, 0.8, and $1.2 \mathrm{mM}$ when the confluence reached $50 \%$. In the timecourse experiments, cells were treated with PAL at a final concentration of $0.5 \mathrm{mM}$ for $0,4,8,16,24$, and $48 \mathrm{~h}$. The pcDNA3.1-VEGFA plasmid was gifted by Dr. Yinchuan Li's lab at Nantong University. Cells were transfected with VEGFA plasmid with Lipofectamine 2000 (Thermo Fisher Scientific) according to the manufacturer's instructions.

MTT assay Cell viability was detected by MTT assay. In brief, cells were seeded into 96-well plates at about $1 \times 10^{4}$ cells/well. Cells were treated with designed concentration of PAL or scheduled time for $0.5 \mathrm{mM}$ PAL incubation after $24 \mathrm{~h}$ of culture. At the end of each time point, $0.1 \mathrm{mg}$ MTT (Sigma-Aldrich) was added to each well, and plates were incubated for $4 \mathrm{~h}$ at $37^{\circ} \mathrm{C}$ away from light. Then, the medium was aspirated and $150 \mu \mathrm{L}$ dimethyl sulfoxide (DMSO; Sigma-Aldrich) was dropped into each well. After incubation on a rotator for $15 \mathrm{~min}$, the absorbance of the solution of each well was detected at a wavelength of $490 \mathrm{~nm}$ using a microplate reader (Thermo Fisher Scientific; Varioskan Flash). The cell viability rate was calculated using the following formula:

Viability rate $(\%)=100 \times(\mathrm{OD}$ value of experimental group / OD value of control group). 
Table 1 Sequences of qRT-PCR primers

\begin{tabular}{lll}
\hline Gene name & Forward primer & Reverse primer \\
\hline GAPDH & GCAATGTTGCCAGTGTCTGT & GCCTTGACCTTTTCAGCAAG \\
CASP3 & CAGAGGGGATCGTTGTGAAG & CATACAAAGAAGTCGGCCTCCA \\
Bax & GGGATGGCCTCCTTTCCTAC & TTCCAGATGGTGAGTGAGGCA \\
Bcl-2 & TTCTTTGAGTTCGGTGGGGTC & TGCATATTTGTTTGGGGCAGG \\
$V E G F$ & ACTTTCTGCTGTCTTGGATG & CTCGGCTTGTCACATCACCG \\
$p 65$ & CCCCACGAGCTTGTAGGAAAG & CCAGGTTCTGGAAACTGTGGAT \\
\hline
\end{tabular}

H9c2 cell apoptosis assessment Exponentially growing cells were plated in 6-well plates at a density of $1 \times 10^{5}$ cells/ well. After culture and treatment, cells were trypsinized and resuspended with binding buffer, and the cell density was adjusted to $1 \times 10^{5}$ cells $/ \mathrm{mL}$. Each tube containing $100 \mu \mathrm{L}$ binding buffer was incubated with $5 \mu \mathrm{L}$ Annexin V-FITC and $5 \mu \mathrm{L}$ propidium iodide (PI) for $15 \mathrm{~min}$ on ice away from light. An additional $400 \mu \mathrm{L}$ of binding buffer was added and the samples were analyzed on a flow cytometer (FACS, Beckman Coulter, Pasadena, CA). Each sample was measured in triplicate.

qRT-PCR Total RNA was extracted from H9c2 cells with TRIzol reagent (Invitrogen, Thermo Fisher, Carlsbad, CA) following the manufacturer's instructions. The RNA was quantified with a spectrophotometer (NanoDrop 2000, Thermo Fisher Scientific) and then reverse-transcribed with PrimeScript $^{\mathrm{TM}}$ RT Master Mix (Takara, Shiga Prefecture, Japan, PR036A). Quantitative real-time PCR (qRT-PCR) was performed with SYBR Premix Ex Taq (Tli RNaseH Plus) (Takara, DRR420A). Measurements were carried out in triplicates and data were normalized to endogenous GAPDH expression. Primers were designed by Primer Express software (Applied Biosystems, Foster, CA) and validated. The sequences of primers used are listed in Table 1. The target genes were amplified by PCR program with 2 stages: stage I: $95^{\circ} \mathrm{C}, 30 \mathrm{~s}$; stage II: $95^{\circ} \mathrm{C}, 5 \mathrm{~s} ; 60^{\circ} \mathrm{C}, 34 \mathrm{~s}$, repeat stage II for 40 cycles.

The expression of each gene was defined as the fold change compared with the threshold cycle $(\mathrm{Ct})$, and relative expression levels were calculated using the $2^{-\Delta \Delta \mathrm{Ct}}$ method by normalization to the housekeeping gene GAPDH. Results were presented as the mean from three independent experiments.

Western blot Cells were harvested at certain time points with pre-cooled phosphate-buffered saline (PBS) and washed three times. Cells were in situ incubated with RIPA lysis buffer on ice for $30 \mathrm{~min}$. The lysates were pipetted and centrifuged at $12,000 \mathrm{~g}$ at $4{ }^{\circ} \mathrm{C}$ for $15 \mathrm{~min}$. The supernatant was collected and protein concentrations were determined using a BCA kit. Total protein (20-100 $\mu \mathrm{g}$ per lane) was separated by SDS-PAGE and transferred to a polyvinylidene difluoride (PVDF) membrane (Millipore, Billerica, MA). The membrane was blocked in 5\% skim milk solution and incubated with anti-VEGF (ab1316), anti-caspase 3 (ab13847), anti-Bcl-2 (ab692), anti-Bax (ab32503), anti-p65 (ab16502), anti-p-JNK (ab124956), anti-JNK (ab208035), anti-ERK (ab184699), anti-p-ERK (ab201015), or antiGAPDH (ab181602) at $4{ }^{\circ} \mathrm{C}$ overnight. Then, membranes were washed and incubated with HRP conjugated secondary antibodies. Protein bands were visualized with ECL Super Signal (Pierce, Rockford, IL). Images were taken using a Tanon 5200 system (Shanghai, China) and the relative gray density was analyzed by ImageJ software (NIH, NY, USA), using GAPDH as an internal control.

Caspase 3 activity assay A sensitive assay kit for the quantification of caspase 3 activity in mammalian cells (K533, BioVision, Milpitas, CA) was taken to the current assay. Briefly, cells were washed and digested by pre-cooled PBS buffer for $10 \mathrm{~min}$. Then, the lysate was incubated at $37^{\circ} \mathrm{C}$ for $2 \mathrm{~h}$ with $50 \mu \mathrm{L}$ of $2 \times$ reaction buffer (containing $10 \mathrm{mM}$ dithiothreitol) and $5 \mu \mathrm{L}$ of DEVD-7-amino-4-trifluoromethylcoumarin (Ac-DEVD-AFC) in each group. The fluorescence intensity of the samples was detected with $400 \mathrm{~nm}$ excitation wavelength and $505 \mathrm{~nm}$ emission wavelength. Data were collected in triplicate and processed with Microsoft Excel 2016 (Microsoft, San Francisco).

Statistical analysis Statistical analysis was performed using SPSS Statistics 24.0 (SPSS Inc., Chicago, IL). All data are presented as mean \pm standard deviation $(\bar{x} \pm S)$, and the time-course data such as those from the MTT assay were analyzed by the unpaired Student $t$-test. Differences between groups were analyzed using one-way ANOVA (analysis of variance), followed by Tukey's test, with significance measured at $* P<0.05$, $* * P<0.01$, or $* * * P<0.01$.

Acknowledgements We appreciated Dr. Yinchuan Li for generously gifting us the VEGFA plasmids.

Author contribution SW and XL conceived and designed the study. $\mathrm{SW}, \mathrm{CZ}$, and YY performed the experiments. SW provided the cells transfected with VEGFA plasmid. SW, XL, SG, and YY wrote the 
paper. XL, YY, SG, and XL reviewed and edited the manuscript. All authors read and approved the manuscript.

\section{Declarations}

Conflict of interest The authors declare no competing interests.

Open Access This article is licensed under a Creative Commons Attribution 4.0 International License, which permits use, sharing, adaptation, distribution and reproduction in any medium or format, as long as you give appropriate credit to the original author(s) and the source, provide a link to the Creative Commons licence, and indicate if changes were made. The images or other third party material in this article are included in the article's Creative Commons licence, unless indicated otherwise in a credit line to the material. If material is not included in the article's Creative Commons licence and your intended use is not permitted by statutory regulation or exceeds the permitted use, you will need to obtain permission directly from the copyright holder. To view a copy of this licence, visit http://creativecommons.org/licenses/by/4.0/.

\section{References}

Bowers SLK, Kemp SS, Aguera KN, Koller GM, Forgy JC, Davis GE (2020) Defining an upstream VEGF (vascular endothelial growth factor) priming signature for downstream factor-induced endothelial cell-pericyte tube network coassembly, Arterioscler Thromb Vasc Biol ATVBAHA120314517.

Cacicedo JM, Benjachareowong S, Chou E, Ruderman NB, Ido Y (2005) Palmitate-induced apoptosis in cultured bovine retinal pericytes: roles of $\mathrm{NAD}(\mathrm{P}) \mathrm{H}$ oxidase, oxidant stress, and ceramide. Diabetes 54(6):1838-1845

Chai W, Liu Z (2007) p38 mitogen-activated protein kinase mediates palmitate-induced apoptosis but not inhibitor of nuclear factorkappaB degradation in human coronary artery endothelial cells. Endocrinology 148(4):1622-1628

Cheng L, Ding G, Qin Q, Huang Y, Lewis W, He N, Evans RM, Schneider MD, Brako FA, Xiao Y, Chen YE, Yang Q (2004) Cardiomyocyte-restricted peroxisome proliferator-activated receptordelta deletion perturbs myocardial fatty acid oxidation and leads to cardiomyopathy. Nat Med 10(11):1245-1250

Chiu HC, Kovacs A, Blanton RM, Han X, Courtois M, Weinheimer CJ, Yamada KA, Brunet S, Xu H, Nerbonne JM, Welch MJ, Fettig NM, Sharp TL, Sambandam N, Olson KM, Ory DS, Schaffer JE (2005) Transgenic expression of fatty acid transport protein 1 in the heart causes lipotoxic cardiomyopathy. Circ Res 96(2):225-233

Czabotar PE, Lessene G, Strasser A, Adams JM (2014) Control of apoptosis by the BCL-2 protein family: implications for physiology and therapy. Nat Rev Mol Cell Biol 15(1):49-63

Ferrara N (2004) Vascular endothelial growth factor: basic science and clinical progress. Endocr Rev 25(4):581-611

Geng Y, Hernandez Villanueva A, Oun A, Buist-Homan M, Blokzij1 H, Faber KN, Dolga A, Moshage H (2020) Protective effect of metformin against palmitate-induced hepatic cell death. Biochim Biophys Acta Mol Basis Dis 1866(3) 165621

Gorgani-Firuzjaee S, Ahmadi S, Meshkani R (2014) Palmitate induces SHIP2 expression via the ceramide-mediated activation of NFkappaB, and JNK in skeletal muscle cells. Biochem Biophys Res Commun 450(1):494-499

Harper SJ, Bates DO (2008) VEGF-A splicing: the key to anti-angiogenic therapeutics? Nat Rev Cancer 8(11):880-887
Heallen TR, Kadow ZA, Kim JH, Wang J, Martin JF (2019) Stimulating cardiogenesis as a treatment for heart failure. Circ Res 124(11):1647-1657

Ho QT, Kuo CJ (2007) Vascular endothelial growth factor: biology and therapeutic applications. Int $\mathrm{J}$ Biochem Cell Biol 39(7-8):1349-1357

Hu N, Zhang Y (2017) TLR4 knockout attenuated high fat dietinduced cardiac dysfunction via NF-kappaB/JNK-dependent activation of autophagy. Biochim Biophys Acta Mol Basis Dis 1863(8):2001-2011

Huang JB, Hsu SP, Pan HY, Chen SD, Chen SF, Lin TK, Liu XP, Li JH, Chen NC, Liou CW, Hsu CY, Chuang HY, Chuang YC (2020) Peroxisome proliferator-activated receptor gamma coactivator 1alpha activates vascular endothelial growth factor that protects against neuronal cell death following status epilepticus through $\mathrm{PI} 3 \mathrm{~K} / \mathrm{AKT}$ and MEK/ERK signaling. Int J Mol Sci 21(19)

Kenny HC, Abel ED (2019) Heart failure in type 2 diabetes mellitus. Circ Res 124(1):121-141

Le Y, Wei R, Yang K, Lang S, Gu L, Liu J, Hong T, Yang J (2020) Liraglutide ameliorates palmitate-induced oxidative injury in islet microvascular endothelial cells through GLP-1 receptor/ PKA and GTPCH1/eNOS signaling pathways,.Peptides 124 170212

Leonardini A, D’Oria R, Incalza MA, Caccioppoli C (2017) V Andrulli Buccheri, A Cignarelli, D Paparella, V Margari, A Natalicchio, S Perrini, F Giorgino, L Laviola GLP-1 receptor activation inhibits palmitate-induced apoptosis via ceramide in human cardiac progenitor cells. J Clin Endocrinol Metab 102(11):4136-4147

Li D, Xie K, Zhang L, Yao X, Li H, Xu Q, Wang X, Jiang J, Fang J (2016) Dual blockade of vascular endothelial growth factor (VEGF) and basic fibroblast growth factor (FGF-2) exhibits potent anti-angiogenic effects. Cancer Lett 377(2):164-173

Li X, Wu Y, Zhao J, Wang H, Tan J, Yang M, Li Y, Deng S, Gao S, Li H, Yang Z, Yang F, Ma J, Cheng J, Cai W (2020) Distinct cardiac energy metabolism and oxidative stress adaptations between obese and non-obese type 2 diabetes mellitus. Theranostics 10(6):2675-2695

Lin YH, Kang L, Feng WH, Cheng TL, Tsai WC, Huang HT, Lee HC, Chen CH (2020) Effects of lipids and lipoproteins on mesenchymal stem cells used in cardiac tissue regeneration, Int $\mathrm{J}$ Mol Sci 21(13)

Listenberger LL, Ory DS, Schaffer JE (2001) Palmitate-induced apoptosis can occur through a ceramide-independent pathway. J Biol Chem 276(18):14890-14895

Lytrivi M, Castell AL, Poitout V, Cnop M (2020) Recent insights into mechanisms of beta-cell lipo- and glucolipotoxicity in type 2 diabetes. J Mol Biol 432(5):1514-1534

Mangali S, Bhat A, Udumula MP, Dhar I, Sriram D, Dhar A (2019) Inhibition of protein kinase $\mathrm{R}$ protects against palmitic acidinduced inflammation, oxidative stress, and apoptosis through the JNK/NF-kB/NLRP3 pathway in cultured H9C2 cardiomyocytes. J Cell Biochem 120(3):3651-3663

Nasser MI, Qi X, Zhu S, He Y, Zhao M, Guo H, Zhu P (2020) Current situation and future of stem cells in cardiovascular medicine. Biomed Pharmacother 132110813

Oka T, Akazawa H, Naito AT, Komuro I (2014) Angiogenesis and cardiac hypertrophy: maintenance of cardiac function and causative roles in heart failure. Circ Res 114(3):565-571

Pradelli LA, Beneteau M, Ricci JE (2010) Mitochondrial control of caspase-dependent and -independent cell death. Cell Mol Life Sci 67(10):1589-1597

Puzyrenko AM, Chekman IS, Briuzhina TS (2013) Horchakova NO (2013) Influence of antihypertensive and metabolic drugs on fatty acids content of lipids in cardiomyocytes of rats with spontaneous hypertension. Ukr Biokhim Zh(1993) 85(4):67-74 
Quan J, Liu J, Gao X, Liu J, Yang H, Chen W, Li W, Li Y, Yang W, Wang B (2014) Palmitate induces interleukin-8 expression in human aortic vascular smooth muscle cells via Toll-like receptor 4/nuclear factor-kappaB pathway (TLR4/NF-kappaB-8). J Diabetes $6(1): 33-41$

Rennel ES, Hamdollah-Zadeh MA, Wheatley ER, Magnussen A, Schuler Y, Kelly SP, Finucane C, Ellison D, Cebe-Suarez S, Ballmer-Hofer K, Mather S, Stewart L, Bates DO, Harper SJ (2008) Recombinant human VEGF165b protein is an effective anti-cancer agent in mice. Eur J Cancer 44(13):1883-1894

Richter C, Schweizer M, Cossarizza A, Franceschi C (1996) Control of apoptosis by the cellular ATP level. FEBS Lett 378(2):107-110

Rodriguez CJ, Allison M, Daviglus ML, Isasi CR, Keller C, Leira EC, Palaniappan L, Pina IL, Ramirez SM, Rodriguez B, Sims M E (2014) American Heart Association Council on, Prevention, C. American Heart Association Council on Clinical, C. American Heart Association Council on, N. Stroke, Status of cardiovascular disease and stroke in Hispanics/Latinos in the United States: a science advisory from the American Heart Association, Circulation 130(7) 593-625

Song M, Finley SD (2020) ERK and Akt exhibit distinct signaling responses following stimulation by pro-angiogenic factors. Cell Commun Signal 18(1):114

Sparagna GC, Hickson-Bick DL, Buja LM, McMillin JB (2000) A metabolic role for mitochondria in palmitate-induced cardiac myocyte apoptosis. Am J Physiol Heart Circ Physiol 279(5):H2124-H2132

Tong M, Saito T, Zhai P, Oka SI, Mizushima W, Nakamura M, Ikeda S, Shirakabe A, Sadoshima J (2019) Mitophagy is essential for maintaining cardiac function during high fat diet-induced diabetic cardiomyopathy. Circ Res 124(9):1360-1371

Vakifahmetoglu-Norberg H, Ouchida AT, Norberg E (2017) The role of mitochondria in metabolism and cell death. Biochem Biophys Res Commun 482(3):426-431

Virani SS, Alonso A, Benjamin EJ, Bittencourt MS, Callaway CW, Carson AP, Chamberlain AM, Chang AR, Cheng S, Delling FN, Djousse L, Elkind MSV, Ferguson JF, Fornage M, Khan SS, Kissela BM, Knutson KL, Kwan TW, Lackland DT, Lewis TT, Lichtman JH, Longenecker CT, Loop MS, Lutsey PL, Martin SS, Matsushita K, Moran AE, Mussolino ME, Perak AM, Rosamond
WD, Roth GA, Sampson UKA, Satou GM, Schroeder EB, Shah SH, Shay CM, Spartano NL, Stokes A, Tirschwell DL, VanWagner LB, Tsao CW, E. American Heart Association Council on, C. Prevention Statistics, S (2020) Stroke Statistics Heart Disease and Stroke Statistics-2020 Update: a report From the American Heart Association. Circulation 141(9):e139-e596

Westermann B (2010) Mitochondrial fusion and fission in cell life and death. Nat Rev Mol Cell Biol 11(12):872-884

Xiong Z, Li Y, Zhao Z, Zhang Y, Man W, Lin J, Dong Y, Liu L, Wang B, Wang H, Guo B, Li C, Li F, Wang H, Sun D (2020) Mst1 knockdown alleviates cardiac lipotoxicity and inhibits the development of diabetic cardiomyopathy in $\mathrm{db} / \mathrm{db}$ mice, Biochim Biophys Acta Mol Basis Dis 1866(8) 165806

$\mathrm{Xu}$ J, Murphy SL, Kockanek KD, Arias E (2018a) Mortality in the United States. NCHS Data Brief 355(2020):1-8

Xu J, Murphy SL, Kochanek KD, Arias E (2020) Mortality in the United States, 2018. Natl Vital Stat Rep 355:7

Xu T, Lv Z, Chen Q, Guo M, Wang X, Huang F (2018b) Vascular endothelial growth factor over-expressed mesenchymal stem cellsconditioned media ameliorate palmitate-induced diabetic endothelial dysfunction through PI-3K/AKT/m-TOR/eNOS and p38/ MAPK signaling pathway. Biomed Pharmacother 106:491-498

Yamagishi S, Okamoto T, Amano S, Inagaki Y, Koga K, Koga M, Choei H, Sasaki N, Kikuchi S, Takeuchi M, Makita Z (2002) Palmitate-induced apoptosis of microvascular endothelial cells and pericytes. Mol Med 8(4):179-184

Yang Y, Cong H, Han C, Yue L, Dong H, Liu J (2015) 12-Deoxyphorbol 13-palmitate inhibits the expression of VEGF and HIF-1alpha in MCF-7 cells by blocking the PI3K/Akt/mTOR signaling pathway. Oncol Rep 34(4):1755-1760

Zhou X, Li Z, Qi M, Zhao P, Duan Y, Yang G, Yuan L (2020) Brown adipose tissue-derived exosomes mitigate the metabolic syndrome in high fat diet mice. Theranostics 10(18):8197-8210

Publisher's note Springer Nature remains neutral with regard to jurisdictional claims in published maps and institutional affiliations. 